Brit. J. vener. Dis. (1965), 41, 199.

\title{
FURTHER STUDIES WITH A SELECTIVE MEDIUM FOR CULTIVATING NEISSERIA GONORRHOEAE*
}

\author{
BY \\ JOHN E. MARTIN, JR., WILLIAM L. PEACOCK, JR., AND JAMES D. THAYER \\ Antibiotics Surveillance and Methodology Laboratory, Research and Development, Venereal Disease Research \\ Laboratory, Venereal Disease Branch, Communicable Disease Center, Public Health Service, U.S. Department \\ of Health, Education and Welfare, Atlanta, Georgia
}

A culture medium that is selective for the gonococcus and the meningococcus has been described recently (Thayer and Martin, 1964). The medium with Polymyxin and Ristocetin added permits isolation of the gonococcus from sites highly contaminated with other bacteria. Overgrowth of gonococcal colonies by the commensal bacterial flora present in rectal, vaginal, and cervical specimens is almost completely prevented.

In addition, the nonpathogenic Neisseria such as $N$. sicca, $N$. catarrhalis, $N$. flava, and others fail to grow or are greatly inhibited. Among the many Gram-negative bacteria prevented from growing is the oxidase positive variant of Mima polymorpha. Although Mima polymorpha is seldom encountered, it may be mistakenly identified as $N$. gonorrhoeae if sugar fermentation tests are not carried out.

This report presents the results obtained by using the Thayer-Martin (TM) selective medium (Wende, Forshner, and Knox, 1964), a conventional chocolate agar medium, and the delayed fluorescent antibody (FA) procedure (Deacon, Peacock, Freeman, Harris, and Bunch, 1960) on specimens from vaginal, cervical, and rectal sites.

\section{Material and Methods}

The medium for conventional plate culture and delayed FA slant comparisons was basal medium (Bacto GC Medium Base) with 1 per cent. haemoglobin and 1 per cent. Difco's Yeast Supplement B (GCBA). The TM selective medium was prepared by adding Ristocetin and Polymyxin B to the GCBA medium. Final concentration of the antibiotics in the selective medium was $10 \mathrm{mcg} . / \mathrm{ml}$. Ristocetin and $25 \mathrm{u} / \mathrm{ml}$. Polymyxin B.

\footnotetext{
Note: Trade names are used for identification only and do not Note: Trade names are used for identification only and do not
represent an endorsement by the Public Health Service or the U.S. Department of Health, Education, and Welfare.

* Received for publication March 24, 1965.
}

Trypticase soy broth (TSB), Baltimore Biological Laboratory, was used to prepare the inoculum.

Material for culture was obtained by $\mathrm{Dr}$ John $\mathrm{H}$. Tiedemann, Fulton County Health Department, Atlanta, Georgia, from asymptomatic female contacts of males with proven gonorrhoea. Vaginal and cervical secretions were collected on sterile cotton swabs and placed in tubes containing $1.0 \mathrm{ml}$. sterile TSB. Rectal cultures were obtained "blind" using a rectal "swube" tube (Aloe Scientific Company). Rectal "swubes" have a special shielded cap which assists insertion of the applicator swab into the rectum and reduces the possibility of contamination during manipulation. The "swube" was inserted approximately 2 inches and the swab rotated while applying slight pressure to maintain contact with the rectal wall. The swab was then placed in $1.0 \mathrm{ml}$. TSB.

Specimens were refrigerated at $4^{\circ} \mathrm{C}$. immediately after collection and were transported from the clinic to the laboratory in an ice bath. This procedure was used to inhibit the growth of concomitant bacteria. Approximately 4 hours lapsed between specimen collection and plate and tube inoculation.

At the laboratory, the swabs were rotated and the excess fluid expressed against the side of the tube. To obtain a homogeneous inoculum, the specimen was mixed by repeated pipetting and $0 \cdot 1 \mathrm{ml}$. of the resulting suspension inoculated on the plates and into the tubes. All plates and tubes were incubated in a candle jar at $35^{\circ} \mathrm{C}$.

FA slides were prepared for staining in the usual manner (Deacon and others, 1960) from the tube cultures after 16 hours' incubation. The plate cultures were examined after 40 hours. Colonies were then selected for identification by fermentation or further isolation.

\section{Results}

The results of cultures on TM selective medium, on a conventional chocolate agar medium, and by the delayed FA procedure on specimens obtained from the vaginal and cervical sites of 77 female gonorrhoea 
contacts are presented. Rectal specimens were obtained from 35 patients. Comparison was made first of the number of patients positive for gonorrhoea by each method, secondly of the number of sites positive by each method, and thirdly, of the ease with which cultures were purified from the primary isolation plate for identification by sugar fermentation reactions.

Table I shows the number of positive patients found by culturing 77 female contacts of gonorrhoea. The TM selective medium grew $51(66 \cdot 2$ per cent.), the conventional medium $45(58 \cdot 4$ per cent.), and the delayed FA procedure identified 39 patients ( 50.6 per cent.) as positive for $N$. gonorrhoeae. When using the number of patients who were positive to one or more testing procedures as the base, the respective positivity rates are $100,88 \cdot 2$, and $76 \cdot 5$ per cent. In other words, the conventional culture failed in 11.8 per cent. and the delayed FA procedure failed in 23.5 per cent. to detect gonorrhoea in cases which were positive on TM medium.

TABLE I

COMPARISON OF CULTURAL AND DELAYED FLUORESCENT ANTIBODY RESULTS IN 77 FEMALE GONORRHOEA

\begin{tabular}{c|c|c|c|c|c}
\hline \multicolumn{2}{c|}{$\begin{array}{c}\text { TM Selective } \\
\text { Medium }\end{array}$} & \multicolumn{2}{c|}{$\begin{array}{c}\text { GCBA Conventional } \\
\text { Medium }\end{array}$} & \multicolumn{2}{|c}{$\begin{array}{c}\text { Delayed Fluorescent } \\
\text { Antibody }\end{array}$} \\
\hline $\begin{array}{c}\text { No. } \\
\text { Positive }\end{array}$ & $\begin{array}{c}\text { Per } \\
\text { cent. }\end{array}$ & $\begin{array}{c}\text { No. } \\
\text { Positive }\end{array}$ & $\begin{array}{c}\text { Per } \\
\text { cent. }\end{array}$ & $\begin{array}{c}\text { No. } \\
\text { Positive }\end{array}$ & $\begin{array}{c}\text { Per } \\
\text { cent. }\end{array}$ \\
\hline 51 & $66 \cdot 2$ & 45 & $58 \cdot 4$ & 39 & $50 \cdot 6$ \\
\hline
\end{tabular}

Results of tests by site from which specimens were collected are shown in Table II. By individual testing procedures, cervical specimens were more productive than vaginal specimens, but the total positive by all methods was the same for both sites, $63 \cdot 6$ per cent. Positivity rates for vaginal specimens ranged from $59 \cdot 7$ per cent. for the TM medium to 36.4 per cent. for the delayed FA; for cervical specimens the rates ranged from 61.0 per cent. for the TM medium to $48 \cdot 1$ per cent. for the delayed FA. Of the 49 positive

TABLE II

SPECIMENS POSITIVE FOR

VAGINAL, CERVICAL, AND RECTAL SITES

\begin{tabular}{|c|c|c|c|c|c|c|}
\hline \multirow{3}{*}{ Method } & \multicolumn{6}{|c|}{ Sites } \\
\hline & \multicolumn{2}{|c|}{ Vagina (77) } & \multicolumn{2}{|c|}{ Cervix (77) } & \multicolumn{2}{|c|}{ Rectum (35) } \\
\hline & $\begin{array}{l}\text { No. } \\
\text { Posi- } \\
\text { tive }\end{array}$ & $\begin{array}{c}\text { Per } \\
\text { cent. }\end{array}$ & $\begin{array}{l}\text { No. } \\
\text { Posi- } \\
\text { tive }\end{array}$ & $\begin{array}{c}\text { Per } \\
\text { cent. }\end{array}$ & $\begin{array}{c}\text { No. } \\
\text { Posi- } \\
\text { tive }\end{array}$ & $\begin{array}{c}\text { Per } \\
\text { cent. }\end{array}$ \\
\hline Thayer-Martin Medium & 46 & $59 \cdot 7$ & 47 & $61 \cdot 0$ & 6 & $17 \cdot 1$ \\
\hline GCBA Medium & 34 & $44 \cdot 2$ & 42 & $54 \cdot 5$ & 2 & $5 \cdot 7$ \\
\hline $\begin{array}{l}\text { Delayed Fluorescent } \\
\text { Antibody }\end{array}$ & 28 & $36 \cdot 4$ & 37 & $48 \cdot 1$ & 1 & $2 \cdot 9$ \\
\hline Total by All Methods & 49 & $63 \cdot 6$ & 49 & $63 \cdot 6$ & 6 & $17 \cdot 1$ \\
\hline
\end{tabular}

vaginal specimens, 94 per cent. were detected by the TM medium, 69 per cent. by the conventional medium, and 57 per cent. by the delayed FA procedure. Of the 49 positive cervical specimens, 96 per cent. were detected by the TM medium, 86 per cent. by conventional medium, and 76 per cent. by delayed FA technique. Seven corresponding cultures of the 33 specimens negative by the delayed FA procedure were positive by ten colonies or less on TM selective medium.

Of the 35 rectal specimens, six were positive on the TM selective medium; two positive cultures were obtained by GCBA, and the delayed FA procedure revealed one positive slide.

\section{Discussion}

Uncontaminated colonies can be obtained from the primary isolation plate of the TM selective medium for identification reactions much more easily than from the conventional medium. Of 46 vaginal cultures positive on the selective medium, one culture ( 2 per cent.) was difficult to isolate and purify; in this case, the contaminant was a yeast. Conversely, in 26 of 34 positive vaginal cultures on conventional medium, gonococci were difficult to isolate and purify, frequently requiring 10 days or more for completion of fermentation reactions. There was no purification problem in the cervical cultures positive on the selective medium; however, purification was a problem in 45 per cent. (19 of 42) of the positive cervical cultures on the conventional medium because of contamination with commensal bacteria. In addition, gonococcal colonies were less numerous on conventional medium than on the TM selective medium.

The delayed FA results in this study are similar to the findings of other workers (Deacon and others, 1960), i.e. 50.6 per cent. positive for female contacts. Broth suspension was used to inoculate the slants instead of the recommended swab method. The delayed FA slant cultures and the TM cultures received the same amount of the homogeneous inoculum. However, the plated medium had approximately ten times the surface area of the slanted tube medium. Failure of the delayed FA to detect 43 per cent. of the positive vaginal cultures and 24 per cent. of the positive cervical cultures might be due to the inhibition of gonococci by concomitant bacteria present in the specimens and to the length of incubation-16 hours for the delayed FA slants compared with 40 hours for the plate cultures. However, the FA method detected five positive specimens from these patients that were overgrown by some strains of Proteus species on the TM selective medium and the GCBA medium. 
No technical difficulties were encountered in the delayed FA procedure and, when morphology was considered, nonspecific staining was not a handicap as has been suggested by Wende and others (1964).

Because of probable failure to obtain material from the rectal crypts, the "swube" tube cannot be recommended for obtaining rectal specimens since it does not permit direct visualization of areas of inflammation. Recently it has been shown (Schroeter and Yobs, 1964) that gonococcal proctitis was found in 35 to 40 per cent. of female patients with urogenital gonorrhoea. In this study an anoscope was used to expose the rectal crypts when obtaining cultural specimens.

Use of the TM selective medium as a tool in the presumptive identification of $N$. gonorrhoeae merits consideration. Positive presumptive diagnosis is based on the finding of oxidase positive colonies that on microscopic examination reveal Gram-negative diplococci which are unconfirmed by sugar fermentation or direct FA identification. In a previous study (Thayer and Garson, 1965) of the bacterial flora of normal uninfected women, it was found that presumptive culture evidence led to 16 per cent. false diagnosis. There were Gram-negative organisms in 12.6 per cent. of such cases so similar in morphology to the gonococcus that sugar fermentations were necessary to rule out this organism. In the present study, Neisseria other than $N$. gonorrhoeae were not found; however, even if present, another study on culturing the nasopharyngeal area has shown that the TM selective medium almost completely inhibits the growth of these nonpathogens (Thayer, Frank, and Martin, 1965).

Confidence in the reliability of TM selective medium for presumptive diagnosis of gonorrhoea is further increased by the finding that the diagnostically confusing Mima polymorpha variant oxidans fails to grow (Thayer and Martin, 1964).

This study has shown that diagnosis from vaginal and rectal specimens by $T M$ selective medium is feasible and has resulted in an improved diagnostic percentage from cervical specimens. The TM selective medium is superior to the delayed FA procedure when incubation of the TM medium is carried out for $\mathbf{4 0}$ hours. In laboratories with limited personnel and facilities, it has been found to be a valuable tool in the handling of large numbers of cultures in a minimum of time.

\section{Summary}

This report represents further comparisons of the result obtained by a selective medium with that of a conventional medium and of the delayed fluorescent antibody technique in the detection of gonococci from 77 female gonorrhoea contacts. Comparison is made of:

(1) The number of positive cultures;

(2) The number of sites positive (vaginal, cervical, and rectal);

(3) The ease with which colonies were purified from the primary isolation plate.

The results showed the TM selective medium to be superior in the three areas of comparison.

It is suggested that the TM selective medium is a useful tool in the presumptive diagnosis of $N$. gonorrhoeae in laboratories with limited personnel and facilities.

The authors wish to express their appreciation to Mr Arzell Lester for his technical assistance throughout this study.

\section{REFERENCES}

Deacon, W. E., Peacock, W. L., Jr., Freeman, E. M., Harris, A., and Bunch, W. L. (1960). Publ. Hlth Rep. (Wash.), 75, 125.

Schroeter, A. L., and Yobs, A. R. (1964). "Digest of Proceedings, 14th Annual Symposium on Recent Advances in the Study of Venereal Diseases", Houston, Texas.

Thayer, J. D., Frank, P., and Martin, J. E. (1965). Amer. J. publ. Hlth, 55, 923.

and Garson, W. (1965). "Bacterial and Mycotic Infections of Man" (Dubos and Hirsch), 4th ed. Lippincott, Philadelphia.

and Martin, J. E. (1964). Publ. Hlth Rep. (Wash.), 79, 49.

Wende, R. D., Forshner, J. G., and Knox, J. M. (1964). Publ. Hlth Lab., 22, 103.

Études supplémentaires utilisant un milieu sélectif pour cultiver le gonocoque de Neisser.

\section{RÉSUMÉ}

Dans cet exposé on compare les résultats obtenus en utilisant un milieu sélectif, un milieu conventionnel et la méthode des anticorps fluorescents après incubation, dans la detection des gonocoques chez 77 femmes contaminées. On compare:

(1) le nombre des cultures positives.

(2) le nombre des endroits où le prélèvement fut positif (vaginaux, cervicaux, rectaux).

(3) la facilité avec laquelle des colonies purifiées furent obtenues à partir de la première boîte d'isolement.

Les résultats montrèrent que le milieu sélectif $\mathrm{TM}$ était supérieur dans ces trois domaines de comparaison On suggère le milieu sélectif TM comme un élément utile de diagnostic pour déceler le gonocoque de Neisser lorsque le personnel et les facilités de laboratoire sont limitées. 